\title{
ANAEROBIC DIGESTION OF SEWAGE SLUDGE USING SEQUENTIAL REACTORS: START- UP AND SYSTEMS STABILIZATION DIGESTÃO ANAERÓBIA DE LODO DE ESGOTO UTILIZANDO REATORES SEQUENCIAIS: PARTIDA E ESTABILIZAÇÃO DOS SISTEMAS
}

\author{
DURVAL R. DE PAULA JR ${ }^{1 *}$, \\ DENIS M. ROSTON², \\ EDSON ABDUL.A. NOUR ${ }^{3}$, \\ LUCIANA M. MORAES ${ }^{4}$, \\ SANDRA APARECIDA R. DE CAMARGO5
}

\begin{abstract}
The objective of this work was the implantation and evaluation of three sludge anaerobic digestion systems. The system A configuration was defined by five continuous flow sequential anaerobic reactors (SAR) with effluent recycling. System B had the same layout, but recirculation was substituted by mechanical mixers installed in each reactor. System $\mathrm{C}$ was composed by only one continuous flow stirred tank reactor. The systems were evaluated by weekly monitoring of physicalchemical parameters. Samples were taken from influent, effluent and intermediary ports during an operation period of 115 days. During the most stable operational period (PHASE II), the results indicated total solids removal rate of 95,40 and $29 \%$, and volatile solids removal rate of 95,34 and $22 \%$, for System A, B and C, respectively. The sequential anaerobic reactors (System A and B) presented better performance than conventional digestor (System C).
\end{abstract}

Keywords: Anaerobic digestion, Sewage Sludge, Sequential Anaerobic Reactors.

\footnotetext{
1*Professor Livre docente, Faculdade de Engenharia Agrícola - FEAGRI/UNICAMP Cidade Universitária Zeferino Vaz, Campinas - SP, Caixa Postal 6011, Brasil, email: durval@agr.unicamp.br

${ }^{2}$ Professor Doutor, Faculdade de Engenharia Agrícola - FEAGRI/UNICAMP

${ }^{3}$ Professor Doutor, Faculdade de Engenharia Civil - FEC/UNICAMP

${ }^{4}$ Professora Doutora, Faculdade de Tecnologia FATEC/ITAPETININGA

${ }^{5}$ Doutoranda, Faculdade de Engenharia Civil - FEC/UNICAMP
} 


\section{RESUMO}

O objetivo deste trabalho foi a implantação e avaliação de três sistemas de digestão anaeróbia de lodo. A configuração do Sistema A foi definida por cinco reatores anaeróbios sequenciais de fluxo contínuo (RAC) com reciclo do efluente. O Sistema B teve a mesma configuração sendo a recirculação substituída por misturadores mecânicos instalados em cada reator. O Sistema C foi composto por somente um reator de fluxo contínuo com mistura. Os sistemas foram avaliados através do monitoramento semanal de parâmetros físicos-químicos. Amostras foram coletadas do afluente, efluente e pontos intermediários durante um período de operação de 115 dias. Durante o período de operação mais estável (FASE II), os resultados indicaram taxas de remoção de sólidos totais de 95,40 e 29\%, e taxas de remoção de sólidos voláteis de 95,34 e 22\%, para os sistemas A, B e C, respectivamente. Os reatores anaeróbios sequenciais (Sistemas A e B) apresentaram melhor desempenho do que o digestor convencional (Sistema C).

Palavras-chaves: Digestão Anaeróbia, Lodo de Esgoto, Reatores Anaeróbios Sequenciais.

\section{INTRODUCTION}

Conventional wastewater treatment plants always generates as by-product the sludge formed in the primary and secondary settling tanks, which needs additional treatment for complete stabilization.

Although there is a trend to apply "lesser sludge production technologies", it is still very frequent the application of conventional systems generating huge volume of sludge.

The final adequate disposal of sludge is a problematic stage in the operational process of a sewage treatment plant and that, normally, has been neglected. The total costs of the sludge treatment units may represent one third of the total investment (VESILIND, 1974) or $50 \%$ of the operational budget (BETTIOL \& CAMARGO, 2000).

Research in the direction to optimize anaerobic digestion through technological development of "new conception systems" has not been explored, stimulating the proposal of this work consisting of installation and evaluation of a sequential anaerobic reactor system (SAR) treating sludge from the primary and secondary sedimentation tanks of a conventional sewage treatment plant.

This proposal is based upon the possibility of improvement of system hydrodynamic conditions, leading to an optimization of mixture condition and better contact substrate-biomass. Also, biochemical reactions involved in the anaerobic process may be favored by the creation of distinct environment conditions in the diverse reactors, providing better process stability and higher system performance.

The main objective of this work was to develop comparative studies of the sludge stabilization process using continuous flow sequential anaerobic reactors and conventional continuous flow stirred tank reactor determining design parameters and optimizing operational procedures.

\section{MATERIAL AND METHODS}

This research was developed at the sewage treatment plant Carioba, located in the city of Americana - SP - Brazil. The pilot plant, illustrated in Figures 1 and 2, was composed by an equalization tank of $2,500 \mathrm{~L}$ volume, which fed 3 anaerobic reactors systems. The first 
system (A), was composed by five continuous flow sequential anaerobic reactors (SAR), each one with a 1,000L capacity with a recycling line from the fifth to the first reactor. The second system, also a "SAR" system, was similar to the first one. The difference of the previous one was the use of slow mixers installed in each reactor. Finally, the third system (C), was composed by only one continuous flow stirred tank reactor with $5,000 \mathrm{~L}$ capacity. The influent in each reactor was introduced near the bottom in order to achieve the best possible even distribution in the tanks.

The pilot plant (equalization tank and reactors) was assembled using water storage tanks made out of fiberglass, promptly available in hardware stores.

The pipeline, valves, and sampling ports were manufactured in PVC, also available in hardware stores. A submerged pump (KSB-KRT Drainer 1500) was utilized to send the sludge to equalization tank. From there, positive shift pumps (Netzsch-3.NU.06), proper for high solids concentration liquids, fed the 3 systems and also were used to recycle the effluent in System A.

The evaluations of the 3 systems were carried out analyzing the following parameters: Total Solids (TS), Volatile Solids (VS), Fixed Solids (FS), pH, Volatile Fatty Acids (VFA), Partial Alkalinity (PA) and Total Alkalinity (TA). TS, VS, FS and $\mathrm{pH}$ determination were carried out according to the Standard Methods for Examination of Water and Wastewater (APHA, 1990). VFA determinations were carried out according methodology proposed by DILALO \& ALBERTSON (1961). TA and PA determination were carried out according methodology proposed by RIPLEY et al (1986). The sampling ports are indicated at Figure 1.

The systems were operated during 115 days under hydraulic retention time (HRT) of 30 days, including PHASE I (Start-up - 55 days) and PHASE II (60 days.

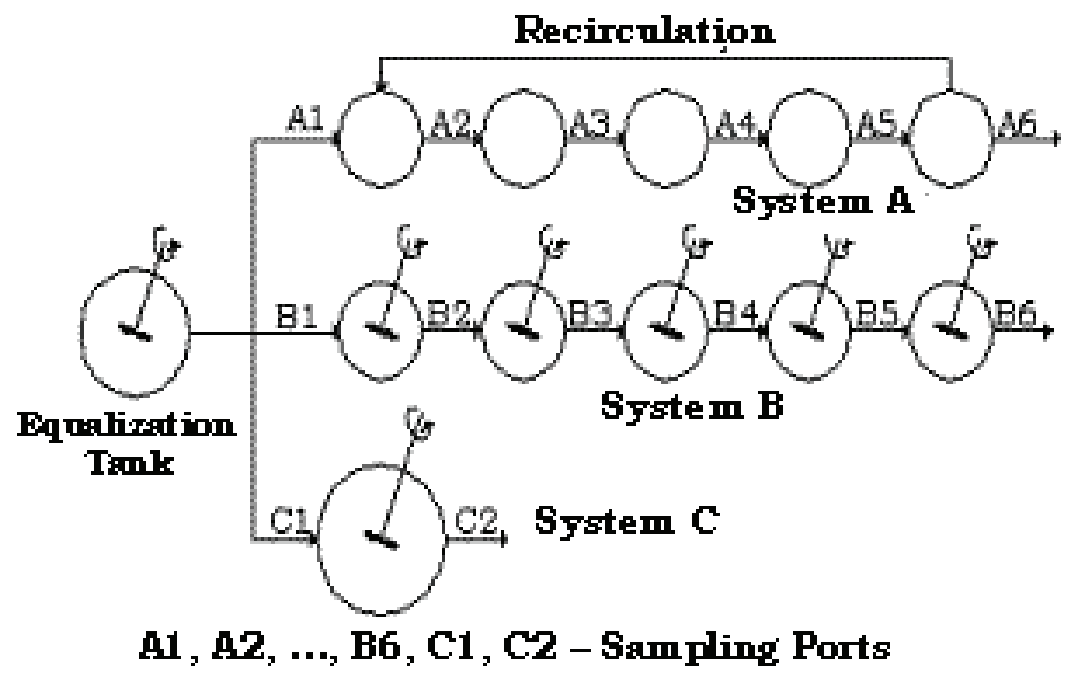

FIGURE 1. Pilot Plant schematic diagram

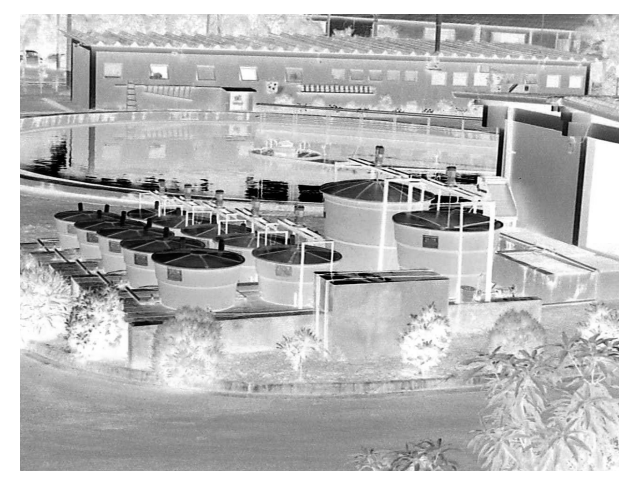

FIGURE 2. Pilot Plant View 


\section{RESULTS AND DISCUSSION}

The average values for the analyzed Start-up, HRT=30 days) and Table 2 (PHASE parameters are shown in Table 1 (PHASE I - II, HRT=30 days).

TABLE 1. Parameters average values during PHASE I (Start-up, HRT=30 days) in systems A, B and C.

\begin{tabular}{|c|c|c|c|c|c|c|c|c|}
\hline \multirow{2}{*}{$\begin{array}{c}\text { Sampling } \\
\text { Ports }\end{array}$} & \multirow{2}{*}{$\begin{array}{c}\mathrm{TS} \\
(\mathrm{mg} / \mathrm{L})\end{array}$} & \multirow{2}{*}{$\begin{array}{c}\text { TS } \\
\text { Removal } \\
(\%)\end{array}$} & \multirow{2}{*}{$\begin{array}{c}\text { VS } \\
(\mathrm{mg} / \mathrm{L})\end{array}$} & \multirow{2}{*}{$\begin{array}{c}\text { VS } \\
\text { Removal } \\
(\%)\end{array}$} & \multirow[b]{2}{*}{$\mathrm{pH}$} & \multirow{2}{*}{$\begin{array}{c}\text { VA } \\
\text { (mg Acet.Ac./L) }\end{array}$} & TA & PA \\
\hline & & & & & & & \multicolumn{2}{|c|}{$\left(\mathrm{mg} \mathrm{CaCO}_{3} / \mathrm{L}\right)$} \\
\hline A1 (influent) & 45217 & \multirow{2}{*}{74} & 30582 & \multirow{2}{*}{79} & 5.1 & 2388 & 790 & 0 \\
\hline A6 (effluent) & 11627 & & 6481 & & 5.7 & 1950 & 970 & 89 \\
\hline B1(influent) & 40378 & \multirow{2}{*}{12} & 28024 & \multirow{2}{*}{9} & 5.1 & 2148 & 709 & 0 \\
\hline B6 (effluent) & 35538 & & 25624 & & 5.4 & 2144 & 860 & 0 \\
\hline C1(influent) & 40605 & \multirow{2}{*}{1} & 27897 & \multirow{2}{*}{2} & 5.1 & 2179 & 738 & 0 \\
\hline C2 (effluent) & 40226 & & 27389 & & 5.8 & 2247 & 1062 & 128 \\
\hline
\end{tabular}

TABELA 2. Parameters average values during PHASE II (HRT=30 days) in systems $A, B$ and $C$.

\begin{tabular}{|c|c|c|c|c|c|c|c|c|}
\hline \multirow{2}{*}{$\begin{array}{c}\text { Sampling } \\
\text { Ports }\end{array}$} & \multirow{2}{*}{$\begin{array}{c}\mathrm{TS} \\
(\mathrm{mg} / \mathrm{L})\end{array}$} & \multirow{2}{*}{$\begin{array}{c}\text { TS } \\
\text { Removal } \\
(\%)\end{array}$} & \multirow{2}{*}{$\begin{array}{c}\mathrm{VS} \\
(\mathrm{mg} / \mathrm{L})\end{array}$} & \multirow{2}{*}{$\begin{array}{c}\text { VS } \\
\text { Removal } \\
(\%)\end{array}$} & \multirow[b]{2}{*}{$\mathrm{pH}$} & \multirow{2}{*}{$\begin{array}{c}\text { VA } \\
(\text { mg Acet.Ac./L) }\end{array}$} & TA & $\mathrm{PA}$ \\
\hline & & & & & & & \multicolumn{2}{|c|}{$\left(\mathrm{mg} \mathrm{CaCO}_{3} / \mathrm{L}\right)$} \\
\hline A1 (influent) & 41136 & \multirow{2}{*}{95} & 25883 & \multirow{2}{*}{95} & 5.7 & 2219 & 1019 & 56 \\
\hline A6 (effluent) & 2211 & & 1264 & & 7.7 & 735 & 1836 & 1207 \\
\hline B1(influent) & 43957 & \multirow{2}{*}{40} & 28748 & \multirow{2}{*}{34} & 5.6 & 2583 & 1067 & 54 \\
\hline B6 (effluent) & 26564 & & 18933 & & 7.5 & 1872 & 1688 & 552 \\
\hline C1(afluente) & 46424 & \multirow{2}{*}{29} & 28969 & \multirow{2}{*}{22} & 5.6 & 2599 & 1063 & 0 \\
\hline C2 (effluent) & 33166 & & 22652 & & 7.5 & 2713 & 2108 & 652 \\
\hline
\end{tabular}


Since solids analysis are the bases for the systems performance, TS and VS evolution

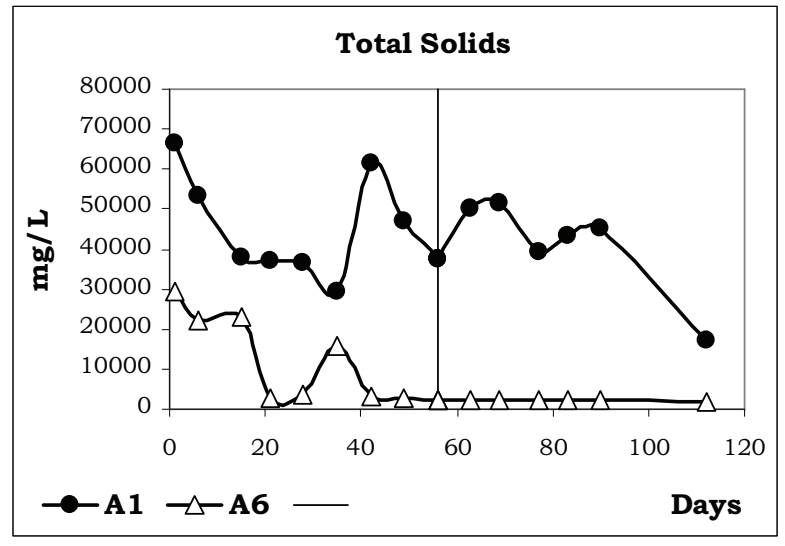

during all operation period, are shown in Figures 3,4 and 5.

Figure 3. Total Solids and Volatile Solids concentration during operational period in System A.
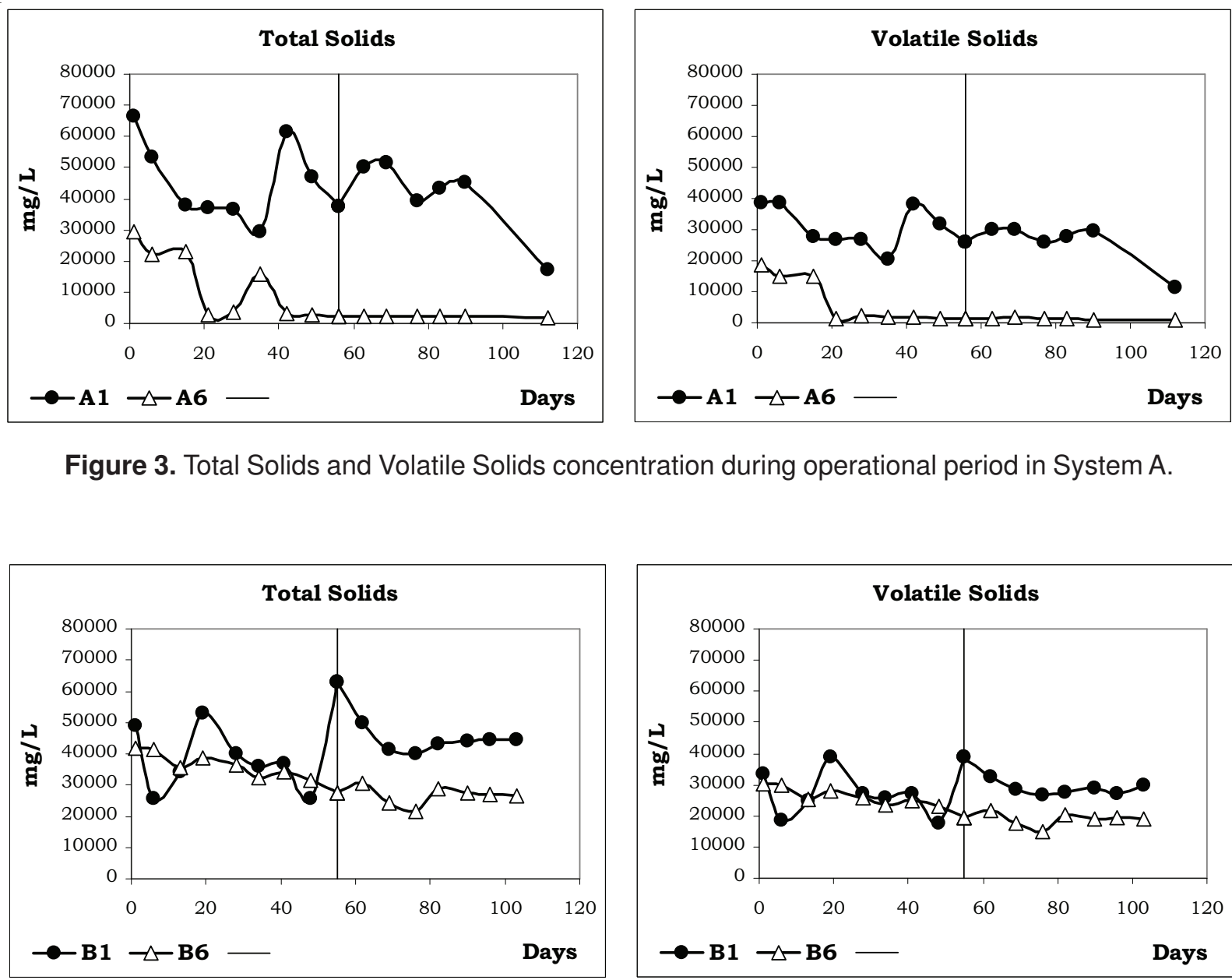

Figure 4. Total Solids and Volatile Solids concentration during operational period in System B.
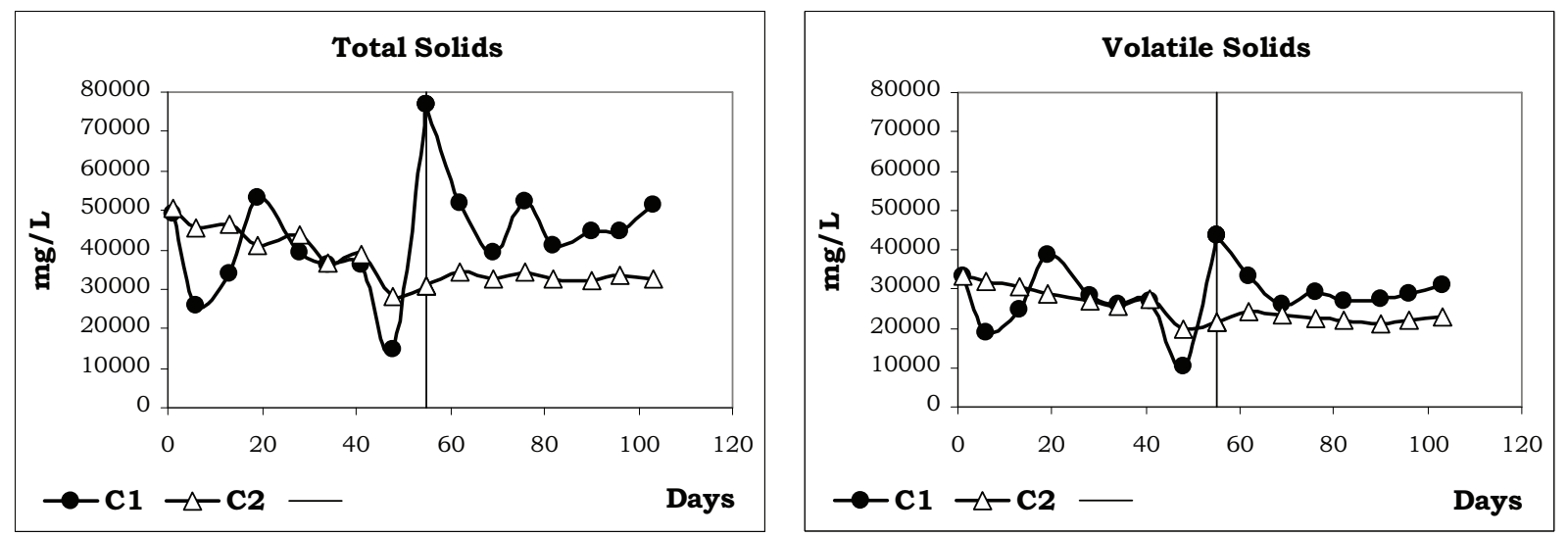

Figure 5. Total Solids and Volatile Solids concentration during operational period in System C. 
The box plot analysis (maximum and minimum values, median, and interquartile range - IQR) is shown in Figure 6 (PHASE I, Start-up) and Figure 7 (PHASE II).
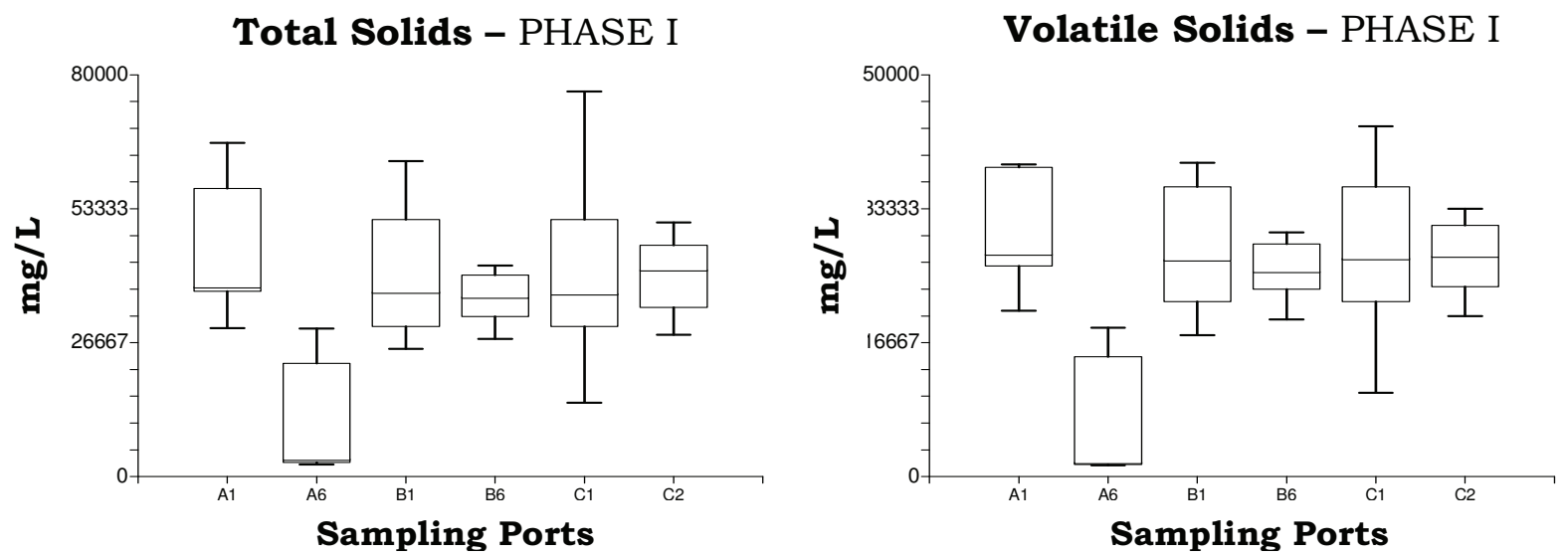

Figure 6. Box plot analysis for TS and VS in PHASE I (Start-up).
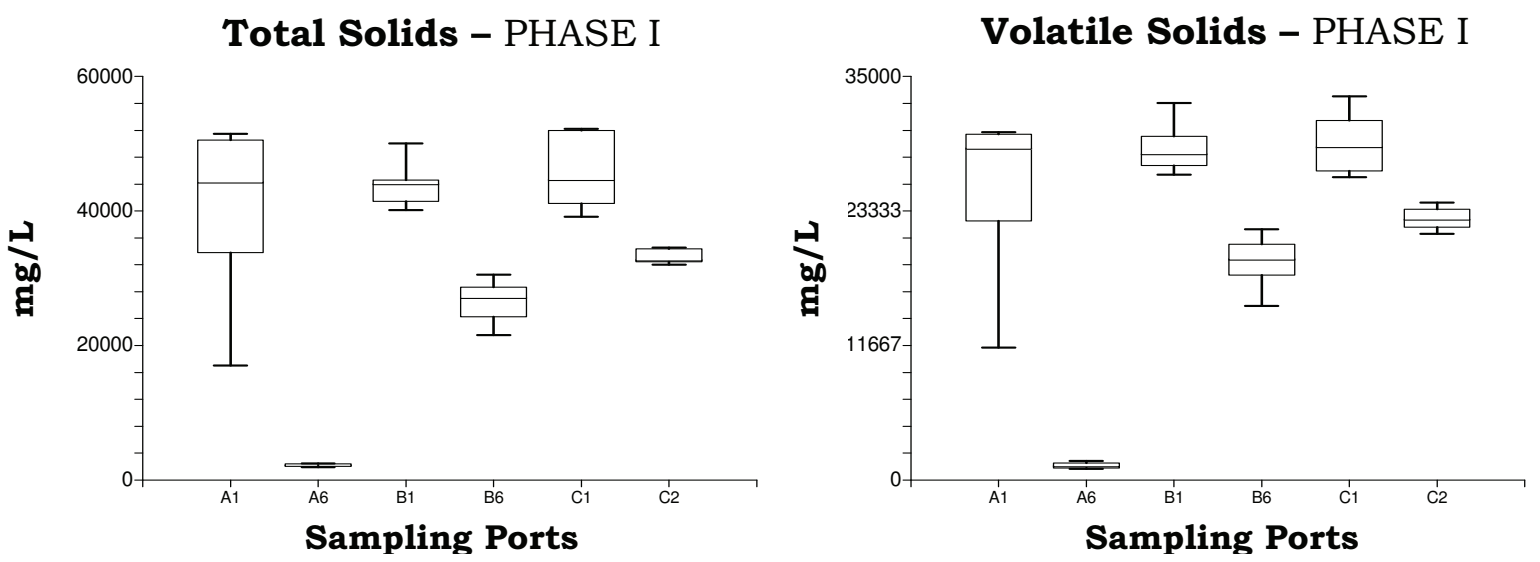

Figure 7. Box plot analysis for TS and VS in PHASE II (Start-up).

From $55^{\text {th }}$ day of operation, the $\mathrm{pH}$ values have indicated a clear trend to stabilization in values next to 7.0 for all systems. This tendency of $\mathrm{pH}$ increase was followed by the increase of alkalinity (total and partial) and by the reduction of volatile fatty acids. This behavior allowed identifying the change of the Start-up period (PHASE I) to the operation period (PHASE II). The hydraulic retention time for this operation period was 30 days. Up to the $55^{\text {th }}$ day operation, as observed in Table 1, the parameters had shown low variability in samples taken from influent and effluent.

Only system A, which has no mixers presented considerable average removal for TS (74\%) and VS (79\%). The solids sedimentation in the reactors (with no mixers) may be the reason for that.
The results of PHASE II, shown in Table 2, indicated an improvement in the performance of the systems A, B and C, compared to PHASE I. All systems presented TS, VS, and VFA reductions and increase of $\mathrm{pH}, \mathrm{TA}$, and $\mathrm{PA}$.

During PHASE II, system A presented average removal of TS and VS up to $95 \%$. The better performance of system A may be observed by the evolution of TS and VS concentration during system A operation. Figure 3 illustrates it. However, the sludge accumulation at the bottom of the reactors must be considered. This fact does not allow a conclusive evaluation for system A performance for a longer period.

System B had better performance than system $C$ removing TS and VS. This is showed in Figures $\mathbf{4}$ and $\mathbf{5}$. Table 2 indicates the system 
B had TS and VS removal efficiency about 10\% higher than system $\mathrm{C}$.

From Figure 6 may be observed high data spread for TS and VS (influent and effluent) for systems $A, B$, and $C$, indicating a non-stable operation period (Start-up). However, Figure 7 shows low data spread for TS and VS (effluent only), indicating a trend for stabilization in systems effluents.

From Figure 7 may be observed better performance for sequential anaerobic reactors (Systems A and B) compared to conventional digester (System $\mathrm{C}$ ) during the most stable operation period (PHASE II).

\section{CONCLUSIONS}

The evaluation of system A, B e C, operated approximately 115 days (including 55 days of Start-up period) allow to conclude that sludge digestion using sequential anaerobic reactors (SAR) presented higher performance than the conventional anaerobic digester for 30 days hydraulic retention time.

The development of simplified technology utilizing the SAR system seems to be viable. Nevertheless, more studies testing other hydraulic retention time are necessary in order to determine design parameters and to optimize of operational procedures.

\section{ACKNOWLEDGEMENTS}

The authors wish to acknowledge the support obtained from the following institutions: Brazilian Financing Agency of Studies and Projects - FINEP and Brazilian Scientific and Technological Development Council - CNPq.

\section{REFERENCES}

AWWA/APHA, WEF (1998) Standard Methods for the Examination of Water and Wastewater. 20 edition. Washington.

BETTIOL, W.; CAMARGO, O. (2000) A. Impacto Ambiental do Uso Agrícola do Lodo de Esgoto, Jaguariúna, SP, 312p.

DILLALO R. \& ALBERTSON O.E. (1961) Volatile acids by direct titration. Journal Water Pollution Control Federation, 33(4), 356-65.

RIPLEY L.E., BOYLE W.C. \& CONVERSE J.C. (1986) Improved alkalimetric monitoring for anaerobic digestion of highstrength wastes. Journal Water Pollution Control Federation, 58(5), 406-11.

VESILIND, P.A. (1974) Treatment and Disposal of Wastewater Sludges, Ann Arbor Science Publishers Inc., EUA, 236 p. 